\title{
GCU
}

Glasgow Caledonian

University

University for the Common Good

\section{Selling second-hand luxury: empowerment and enactment of social roles}

Turunen, Linda Maria Lisa; Cervellon, Marie-Cécile; Carey, Lindsey Drylie

Published in:

Journal of Business Research

DOI:

10.1016/j.jbusres.2019.11.059

Publication date:

2020

Document Version

Author accepted manuscript

Link to publication in ResearchOnline

Citation for published version (Harvard):

Turunen, LML, Cervellon, M-C \& Carey, LD 2020, 'Selling second-hand luxury: empowerment and enactment of social roles', Journal of Business Research, vol. 116, pp. 474-481. https://doi.org/10.1016/j.jbusres.2019.11.059

\section{General rights}

Copyright and moral rights for the publications made accessible in the public portal are retained by the authors and/or other copyright owners and it is a condition of accessing publications that users recognise and abide by the legal requirements associated with these rights.

Take down policy

If you believe that this document breaches copyright please view our takedown policy at https://edshare.gcu.ac.uk/id/eprint/5179 for details of how to contact us. 


\title{
Selling second-hand luxury: empowerment and enactment of social roles
}

\begin{abstract}
Consumption of luxury goods is morphing into a diverse proposition where consumers are actively adopting new roles: besides buyers and users, they are sometimes becoming sellers of luxury branded products. This paper examines meanings and values attached to the process of selling luxury goods. To investigate this issue, eighteen women who had previously sold luxury branded items were interviewed. The findings demonstrated that the act of selling luxury goods challenges and shapes conventional meanings attached to luxury: Firstly, there is an alteration to the symbolic value of the item. The process around selling strips luxury items down to the object of a financial transaction hereby empowering the consumer. Secondly, consumers who sell luxury items engender change in their social role. For some, the act of selling used luxury items enabled a perceived higher social status, and for others it contributed to the boosting of their role as a sustainable consumer.
\end{abstract}

Key words: luxury, second-hand, status, sellers 


\section{Introduction}

The second-hand luxury market is in vogue; in particular, the personal luxury goods market is developing, attracting younger generations of consumers. Boston Consulting Group (BCG) true luxury global consumer report (2019) estimates the second-hand personal luxury market at over 20 billion Euros, underpinning an annual growth of 12\%, especially in Europe. The fast development of online channels - peer-to-peer marketplaces, hosted apps dedicated to second-hand and specialized platforms - confer worldwide visibility to pre-owned luxury goods; four out of five participants on the second-hand luxury market get informed and trade online (BCG, 2019). The growth of the second-hand luxury market is influenced by shifting attitudes and renewed acceptability related to wearing and owning previously used goods (e.g. Ferraro et al., 2016; Beard, 2008). It has also become a way of embracing sustainability (Carrigan et al., 2013), finding rare and unique pieces (Cervellon, Carey \& Harms, 2012; Turunen \& Leipämaa-Leskinen, 2015), and accessing luxury brands which would normally be out of reach financially (Amatulli et al., 2018).

The growth of the second-hand luxury market has steadily raised interest among academic researchers over the last seven years; research has focused on understanding the motivations of consumers of second-hand and vintage luxury (Cervellon et al., 2012; Amatulli et al., 2018; Kessous \& Valette-Florence, 2019) and the meaning attached to pre-used luxury goods (Turunen \& Leipämaa-Leskinen, 2015). The studies show how second-hand luxury purchasers are driven by functional, psychological and emotional as well as symbolic determinants. Second-hand luxury goods, in equal measure to brand-new luxury, might be used as a basis for self-extension and selfrepresentation (Belk, 1988).

This far, research has focused on consumers as purchasers of pre-owned luxury, and has neglected an important actor on the market: the sellers. Yet, the particularity of the second-hand market is that 
it operates out with the locus of control of luxury brands (in most cases), and is driven by the disposal of pre-owned goods. Sourcing is a key factor of success for second-hand luxury intermediaries. The second-hand market involves transactions between purchasers and sellers, hence the word "second-hand consumers" which covers multiple realities. To contribute to the existing luxury literature, we aim to understand luxury sellers' behaviour. This research investigates how consumers selling pre-owned luxury artefacts construct the personal and social value attached to luxury goods. We argue in our paper that second-hand luxury sellers are changing the conventional luxury market's power-dynamics: besides transforming sacred items with a personal meaning into profane goods sold for money, selling luxury alters the symbolic and personal value of the product. Furthermore, it is not within the sole remit of luxury companies to create and manage consumer status on the first-hand market (Dion \& Borraz, 2018), but increasingly, the seller-purchaser interactions on the second-hand market affect consumers' social role and perceived social value of luxury goods. Status, the admiration and respect sought after by many luxury consumers, might be gained in an unconventional way, through selling.

Building understanding about sellers' consumer behaviour is valuable for luxury brands, as disposal activities such as selling are closely associated with purchasing new products (Cruz-Cárdenas \& Arévalo-Chávez, 2018). In addition, consumers who sell, play a crucial role in shaping the perceived symbolic and financial value of luxury branded products. The price records that several Hermès bags have reached on the second-hand market influence significantly the brand value, as Hermès bags are perceived as an investment. Sellers also contribute to the democratization and accessibility of luxury at a broader level. The more attractive and efficient the second-hand market becomes, the more it plays a role and affects those who buy the brand-new luxury items (Chu \& Liao, 2010; Liao \& Chu, 2013). 
The following sections define the key concepts of the paper and review previous academic research on perceived personal and social value of luxury consumption. The research methodology and findings are presented in sections three and four. Finally, we discuss our contribution to the luxury literature, and suggest the managerial implications for luxury brands and second-hand intermediaries yielded by this research.

\section{Theoretical background}

\subsection{Defining second-hand luxury}

Second-hand luxury is defined through the characteristics of the products transacted: second-hand luxury products are previously owned, generally used, luxury branded items (Turunen \& LeipämaaLeskinen, 2015) that are sold on alternative - "secondary" - channels. Thus, the transactions often lack the experiential facets offered through conventional luxury channels (Cervellon \& Vigreux, 2018). The price of those goods is usually lower than when purchased first-hand in the designated luxury boutiques (to the exception of certain limited editions and rare iconic models). As an example, on the platform 'Vestiaire Collective', prices of second-hand luxury are between $30 \%$ and $70 \%$ lower than the price of the goods purchased first-hand (vestiairecollective.com, 2019). The principle distinction of second-hand luxury compared to first-hand luxury remains the price accessibility of the goods and the extension it affords the product lifecycle (Cervellon et al., 2012).

The concept of vintage overlaps with second-hand luxury, but the terms are not interchangeable. Vintage refers to age, to history, to periods or specific past eras (Gerval, 2008; Cervellon et al., 2012). Vintage products are testimonies of the past. Most second-hand platforms label "vintage" 
goods that are at least older than ten years (vestiairecollective.com, 2019). These goods derive their value from their rarity on the second-hand market. They might be branded, or not, by luxury brands. Often, sellers of vintage goods are professionals and specialists of certain eras (60's, 70's).

Second-hand and vintage items do not necessarily attract the same profile of consumers: Cervellon et al. (2012) conclude that second-hand purchases relate to price-consciousness and frugality, and Kessous and Valette-Florence (2019) added that eco-friendliness, status-driven bargain-hunting and even social-climbing, might also be determinants of second-hand luxury purchases. Vintage consumption, conversely, is driven by nostalgia, need for uniqueness, and timelessness (Cervellon et al., 2012; Amatulli et al., 2018). In summary, second-hand luxury goods, including vintage, have symbolic properties that can help buyers express and enhance their personal and social identities.

\subsection{Perceived personal value of luxury consumption}

Scholars have examined luxury consumption through the lens of self-concept and self-extension theories (Belk, 1988). Luxury acquisition and usage might be justified by the expression and enhancement of the social self, projecting status to others, for instance, but also of the private self, related to hedonic and experiential motivations (Gil et al., 2012). Berthon et al. (2009) put forward this personal and experiential dimension of luxury, which is often overshadowed by the symbolic and social dimensions. According to Vigneron and Johnson (1999), luxury consumers derive selfdirected benefits when acquiring and using luxury products: intrinsic, sensory and aesthetic, pleasure (perceived emotional value) and the feeling of attaining perfection (perceived quality

value). Hagtvedt and Patrick (2009) go further in defining a luxury brand as "one that has premium 
products, provides pleasure as a central benefit, and connects with consumers on an emotional level".

In addition, with second-hand consumption, the acquisition of the luxury goods may also drive emotional benefits related to treasure hunting (Turunen \& Leipämaa-Leskinen, 2015; Amatulli et al., 2018), and the intrinsic pleasure of possessing a high quality product, purchased at a lower price (Cervellon et al., 2012). From the sellers' perspective, the experiential and personal drivers of second-hand consumption are theorized mainly through disposal behaviour, where selling represents one aspect of disposal. Lee et al. (2015: 467) point out that selling is often chosen as a method to dispose of luxury goods as "luxury goods encounter a greater amount of perceived financial and psychological costs due to their high price and strong symbolic values". More precisely, Lee et al. (2015) suggest that values engendered by luxury possessions - cognitive (quality and economic) and emotional (symbolic and experiential) - create a perceived switching cost upon disposition. Based on the perceived switching cost, the consumer chooses a specific disposition method, such as selling it on. This suggests that disposing of luxury goods through selling is a meaningful process that has a personal resonance to the seller. If the product carries a negatively charged meaning from the past, the disposition might bring relief, when the product carries positive memories, owners might enter into divestment rituals to wash the personal meanings out of the good (McCracken, 1986; Noble \& Walker, 1997). We contribute to the luxury literature by investigating the meaning and the personal value of selling pre-owned luxury goods.

\subsection{Perceived social value of luxury consumption}

Moving on from the personal value of luxury, the dominant theories explaining luxury consumption emphasize the perception made about luxury consumers in social settings. As early as the $19^{\text {th }}$ 
Century, Veblen (1899) proposed that people consume conspicuously in order to demonstrate their wealth to others. Based on Veblen's theory, Bearden and Etzel's (1982) research indicates that the conspicuous display of luxury goods infers status and wealth. Conspicuous consumption theories highlight the importance of public display of status-laden possessions (O'Cass \& McEwen, 2004). Closely related, status consumption theories point to a "motivational process by which individuals strive to improve their social standing" (Eastman et al., 1999: 42) and implies the consumption of products that symbolize internal or external status. The motivation to consume luxury goods based on a need for status and the facilitation of social climbing has been investigated through experimental designs. In Han et al. (2010), consumers with a high need for status were more likely to choose status-laden products with prominent logos, in order to assimilate with their aspirational groups. In addition, the desire to project towards a successful position leads to the preference for luxury brands (Mandel et al., 2006). This perceived social value of luxury goods is based on the display of brands that underpin and facilitate privileged-group memberships (Vigneron \& Johnson, 1999; Cervellon et al., 2012). Academic research (Nelissen \& Meijers, 2011) indicates that, the display of status signals is conducive to preferential treatments and privileges.

Research suggests that status-seeking goals might be achieved through two distinct luxury consumption behaviours: Bandwagon and Snob. Leibenstein's (1950: 189) seminal work describes the Bandwagon effect as the extent to which the demand for a good is increased due to its popularity; in contrast, the Snob effect is described as the extent to which a good is rejected when it is perceived to be adopted by the masses. Through both behaviours, consumers acquire status: the bandwagon behaviour leads to association with the affluent group whilst the snob behaviour leads to dissociation from the majority of luxury consumers to facilitate the expression of one's uniqueness (Kastanakis \& Balabanis, 2014). A large body of literature has investigated how consumers use luxury goods to signal status through bandwagon and snob consumption (see 
Kastanakis \& Balabanis, 2014 for a review). Based on the second-hand luxury literature (Kessous et al., 2017; Amatulli et al., 2018), one could argue that purchasing second-hand goods for social climbing reasons might be symptomatic of bandwagon behaviour and purchasing vintage, rare, aged goods in a need for uniqueness might indicate a snob effect. Yet, no academic studies have examined how selling luxury goods can be regarded as a form of conspicuous consumption or status signaling. Belk, Sherry and Wallendorf (1988: 466) suggest that the act of selling may contribute "to keep used goods within the same social class rather than passing them on to a lower or more needy, social class" through donations. Yet, we could argue that selling is also a way to get rid of luxury goods that have been popularised and to establish status though social distance with a 'bandwagon' group of consumers. The second contribution of this research is to investigate the perceived social value derived from selling luxury possessions on the second-hand market, in relation to the symbolic benefits derived from the financial transaction and role-playing.

\section{Methodology}

Women were recruited via Facebook buy and sell groups, second-hand platforms (when direct messaging was possible e.g. LeBonCoin and Vinted) and through personal relationships. They were screened on a number of criteria. Stores and professional resellers whose reselling is the main professional activity were excluded. Participants selected were reselling personal items that had not routinely been sourced initially for resale and had mainly been purchased for self-use. Women were selected, as they are the first source of sales on second-hand luxury fashion platforms. All women selected had sold or were selling second-hand luxury handbags on the second-hand market (online

and in specialized boutiques), from Longchamp (entry-level luxury) to Hermès (high-end luxury). In 2018, 44\% of all second-hand luxury purchases were handbags (BCG, 2019). Aside from 
handbags, these women were active sellers over a number of years, selling personal luxury goods, from belts and scarfs (low-ticket items) to jewellery, watches and fur (high-ticket items). The second-hand market, being a global marketplace for sellers and buyers, the women originated from four European countries: Finland, France, Italy and the United Kingdom. Women were aged 26 to 63 years old (see Table 1 for summary of participants' characteristics).

\begin{tabular}{|c|c|c|c|}
\hline Name & Age & Country & Sample of luxury brands sold: \\
\hline 1. A & 20 's & Italy & Lancel, Longchamp, Gucci \\
\hline 2. $\mathrm{O}$ & 20 's & Finland & DKNY, Alexander Wang \\
\hline 3. $\mathrm{C}$ & 20 's & France & Balenciaga, Balmain, Gucci \\
\hline 4. B & 20 's & Finland & Valentino, Louis Vuitton \\
\hline 5. L & 30 's & British & Hermès, Louis Vuitton, Chanel \\
\hline 6. K & 30 ’s & Finland & Chloe, Gucci, Tods \\
\hline 7. T & 30 's & Finland & Celine \\
\hline 8. M & 30 's & Italy & I.Marant, Chanel, Balmain, Lancel \\
\hline 9. $\mathrm{H}$ & 40’s & Finland & Gucci, Louis Vuitton \\
\hline 10. D & 40 's & Italy & Gucci, Louboutin, Prada, Louis Vuitton \\
\hline 11. E & 40’s & Finland & Prada, YSL, Marc by Marc Jacobs \\
\hline 12. $\mathrm{X}$ & 40’s & Finland & Celine, Mulberry \\
\hline $13 . \mathrm{J}$ & 50 's & France & Chloe \\
\hline 14. $\mathrm{N}$ & 50 's & France & Longchamp, Lancel, Kenzo \\
\hline 15. $\mathrm{S}$ & 50 's & British & Hermes, Lonchamp \\
\hline 16. F & 50 's & British & YSL \\
\hline 17. P & 50 's & France & Dior, Celine, Tiffany, Ferragamo \\
\hline 18. V & 60’s & British & Burberry, Fendi \\
\hline
\end{tabular}

\section{Table 1. Interviewees}

Participants completed an agreement to participate in the study. We understood very early on in the process, that many sellers were reluctant to talk about their selling activity, for a variety of reasons that will be discussed in section 4 . The names of the informants were anonymised. Eighteen interviews were necessary to reach saturation point. The interviews were conducted in the native language of the informants by authors, along semi-structured guidelines. Topics included 1) informants' consumption and possession of luxury goods; the meaning attached to luxury goods 2) the goods that the informants had disposed of; the reasons for the disposal; the history, symbolic meaning and feelings associated with the goods 3) the selling process; the distribution channels; the benefits and barriers to selling 4) the purchasing process; purchasing brand-new goods and secondhand; the benefits and barriers to purchasing second hand luxury. Informants were prompted to go 
deeper in their answers mirroring a soft-laddering approach (Grunert \& Grunert, 1995), to unravel the subjective meaning attached to both luxury reselling on the second-hand market and luxury purchasing. Interviews were taped and transcribed into English. The average length of the interviews was one hour.

Data analysis followed Spiggle's (1994) framework: categorization, abstraction, comparison, dimensionalization, integration, iteration, and refutation. Through analysis of the data, different themes emerged, were coded, recoded and grouped again (Belk et al., 2013). The authors, from different cultural backgrounds, helped triangulate the data and introduce a level of "cultural distance" to the interpretation of the themes.

\section{Findings and discussion}

All our informants engaged in both luxury purchase and resell activities regularly. Yet, the focus of the analysis is the reselling activity of our respondents and the meaning they attach to selling luxury goods. Thus, luxury purchases are discussed in the light of their planned or non-planned disposal or selling, and the meaning that the respondents attach to them and to the activity itself. On this basis, five themes emerged from the analysis and were grouped along two dimensions that demonstrate the underlying values of selling luxury goods: 1. the personal value of selling luxury: emotional detachment and financial empowerment; 2. the social value of selling luxury: Sellers' enactment of their social role.

\subsection{The personal value of selling luxury: emotional detachment and financial empowerment}


The personal value of purchasing and using luxury goods lies in the experience of the purchase in the prescribed luxury boutiques, in the hedonic, sensory and aesthetic pleasure of the good per se, and in the emotional connection with the possession (the souvenirs attached to a gift, the reward of a success for instance). Selling luxury entails a different personal meaning: the good is divested from its emotional value and is reduced to a financial investment. In doing so, sellers claim a sense of empowerment.

\subsubsection{Detachment from past symbolic meaning}

If Young and Wallendorf (1989) rightly argue that the disposal process is "the process of detachment from self", the process of selling luxury goods started for our informants as a "process of detachment from the past-self'. Informants retained detailed memories of the first goods they sold and of the "critical events" that led them to sell a luxury possession for first time (Roster, 2001). The decision to sell for first time usually occurred during a stage in their lifecycle of high significance: J moved away from China and decided it was a good time to dispose of clothes that she did not wear regularly; P was turning 40 when she decided she would make space in her life and in her cupboard; D was living a painful personal separation and sold the gifts received from her boyfriend. These respondents sold "contaminated possessions" (Belk, 1988) as reminders of their past. The disposal of luxury goods might yield negative emotions and negative meanings attached to a self that the consumer does not want to be anymore (Lastovicka \& Fernandez, 2005). N sold the gifts from her husband, a symbol of her financial dependence, and is consequently able to start a new life on her own:

"When I was living with my husband, I had a lifestyle that could justify wearing luxury outfits. Then I got a divorce. I had to get rid of lots of stuff, erase aspects of my previous 
life... In a way, this divorce was a renaissance. I could reinvent my life; I changed my style. I gained financial independence. Selling became my new hobby.” (N, 50's)

During transition periods, consumers usually tend to rely on possessions that symbolize their past as well as possessions that represent their new life (Noble \& Walker, 1997). In contrast, for some respondents selling a luxury good for first time symbolizes simultaneously a detachment from a highly valued past, represented by a high value good, and empowerment and control of the present. This control is embodied through disposal behaviour for monetary gain. For P and M, the gifts attached to the past (gifts from loved ones, self-gifts) lose their emotional value as they take on a financial one.

“Once, I realized I had plenty of clothes I was not wearing. I turned 40 years old; I guess I wanted a change in my life. We accumulate too much stuff that we do not use. (...) I guess men change their wives and we change our clothing style when turning 40 (laughs).” (P, 50 's)

The disposal of luxury goods contributes to the construction of a new self or to a reconstruction when self-esteem was undermined. The luxury good is reduced from meanings to its financial value and becomes the object of a financial transaction. The decision process that leads to keeping or selling it for money, entails an evaluation of the emotional bond that ties the consumer to the object. "I entered into a phase of depression when I lost my job. When you hit rock bottom you can only go up. I sold the first expensive good I had purchased by myself with my first salary: a leather jacket by Balmain. The objective was to get money back. Actually, it was the starting point of something bigger. I had the feeling I was in business.” (M, 30's) 


\subsubsection{Divestment from emotional value}

Lee et al. (2015) report the emotional discomfort that might result from disposing of luxury goods, leading to relational switching costs. Consumers might consider a high psychological perceived risk when disposing of luxury goods, regretting the disposal for little money or breaking the relational bonds when giving away gifts from significant others. Yet, when the decision to sell is taken, narratives of sellers are devoid of emotion regarding the item itself. They mention no regrets, no ambivalent feelings, no difficulty with the act of detachment from the goods. As $\mathrm{N}$ mentions, the relationship between the object and the self is definitively broken, akin to the end of a love affair: "If an item has a strong meaning for me, but I do not use it for some reason, I'll give it to friends or relatives; I would not sell it. They will take good care of it and I will enjoy seeing it again on occasion. I sell objects that I do not like anymore or wear or see in my cupboard. I sold a pair of Dior shoes for 50 euros. They were so used I could not wear them although I had loved them so much. I do not have any emotional connection with the objects I sell. Just like in a love affair, when it is over, it is over. [...] On the other hand, I keep jewels that I will give to my sons as a family heritage" (N, 50's)

Detachment is paramount for the transaction to evolve; objects selected for selling have to be devoid of emotional attachment by some means. Ultimately, the intention to sell might lead to a denial of possession, as per the quote below where the language of possession is only related to objects of sentimental or significant value (which are treasured) and where the items being sold have already a status of ex-ownership:

“..usually if it's a gift, there is a lot of meaning behind it - a lot of sentimentality- or maybe, if it's an outfit that I have worn to my son's wedding - something like that - the memories 
are imprinted and it's very difficult to sell that one - so I just sell other people's things and hoard my things.” (V, 60’s)

McCracken (1986) suggests that meaning is erased from possessions when storing them away; luxury goods would be devoid of personal meaning as long as they become the object of a financial transaction. When the item is priced and displayed online, the good is removed from the wardrobe, placed in its box and put aside until the moment it will be purchased. This transition place helps crossing the boundaries between what is me and what was me (Lastovicka \& Fernandez, 2005). Respondents, like D, allocate a special place in their wardrobe to the goods they sell.

"I organized in my dressing a place where I put aside the items I want to dispose of. I protect them from dust, and I do not make the mistake of wearing them anymore. It is very important for the shoes. The pictures of the sole have to be respectful to the condition of the shoes. Regularly, I have clothes that move from the "wearable" place to the "not fashionable" place. I expect the turnover to be fast, because the dressing area is small. After a while, if I do not manage to sell an item, I give it to a charity. In my mind, it is not mine anymore anyway." (D, 40’s)

During the selection process, those goods that are not worn regularly are under scrutiny; the decision to keep an item that does not correspond to a self-image is based on memories and linked to positive emotions. J would not sell the outfit she wore to her son's wedding. M would not sell her $20^{\text {th }}$ birthday present. The beloved possessions are, in this case, extensions of the self (Belk, 1988). "I do not sell objects that have a special resonance in my life. Even if I do not like or wear them. For instance, I will never sell the necklace I received on my $20^{\text {th }}$ birthday. I keep it for my daughter. I understand it might be a burden for her, a heritage that you cannot sell...I hope she will never need the money and have to sell it. [...] I have gained experience now. 
When I purchase a luxury good, I know if I am likely to resell it or not. New collections with very visible logos, I know I will get tired of them and for sure, I will resell them. When I know I want to keep a purchase, I personalize the item." (M, 30's)

As suggested above, gift giving as well as personal memories capture and transfer meaning to a specific product and make it emotionally relevant - something never to be sold. Although $\mathrm{M}$ is in her 30's, she has already started building stories of transmission that transform luxury goods into identity markers and totems of family cohesion (Kessous et al., 2017). She organizes her new purchases according to products she will resell, which are not invested emotionally, and products she keeps, iconic, expressions of herself. Personalization confers an emotional and personal resonance to the goods. Yet, this decreases the financial value on the second-hand market and makes them hard to sell. Similarly, K classifies her bags as come-and-go luxury fashion fads and iconic treasures that she considers as long-term loves. The relationship that started long before ownership of the items cannot be broken (Fournier, 1994):

"I sold the Gucci belt as well as the See by Chloé bag, because they reminded me of my younger years. Besides the brand, it is their aesthetics that used to be trendy back then. But I feel that now, being $30+$, I want my style to be more classic than before. Compared to those fashionable items that are good to go, I would never sell my Hermès bag. It is an iconic handbag and in that way sacred; something I have dreamed of for a longtime and waited for, for years." (K, 30’s)

\subsubsection{Gaining financial empowerment}

Sellers might enter into a speculative process, purchasing limited editions to resell them with a substantial margin, often priced higher than the full price in the boutiques. Besides enabling 
monetary gain from the handbag transactions, consumers support their affluent lifestyle through the constant flow of buying and selling. For example, B was thrilled about "playing against the system". She was constantly building her knowledge about the resale value of handbag brands, and explored something to invest in, as well as scouting the arising fashionable it-bags she wanted to possess. Expertise and financial independence convey a sense of empowerment.

"I justify the luxury handbag purchases to myself by thinking of them as an investment. Basically, when I buy a handbag for thousands of euros, I know I can sell it around 200$400 €$ less after using it for couple of years. With that money, I can buy the new one. It feels like I get handbag worth thousands of Euros for the price of $200-400 €$. This is just the real cost of the bag. Of course, you need to know what to buy. Not all brands hold their value in same way." (B, 20’s)

The participants, who can be considered as entrepreneurial, are not yet professional sellers, although they are sometimes moving towards it. For them, the value of the luxury goods relates to the financial and symbolic value of the product rather than the emotional value. Although they might purchase the product for their personal usage, they see the business value in it and plan their purchase and usage behaviour based on this. They therefore gain on two fronts, during the buying act, they favour the symbolic value of the purchase and during the re-selling act they focus on its financial reward. Additionally, it is clear that they do not see themselves as the end-users of the luxury branded product. For instance, the calculative B is involved in the act of buying and selling for symbolic reasons and especially for status boost:

"I like to always have the IT-bag, which means that I need to surf on the wave all the time with buying and selling. People are always commenting my new bags, sometimes they ask how do I have so much money as I always carry new one. I like to get noticed, but rarely tell 
the truth to anyone. Truth is, I possess at the same time only four bags, of which two is always ready to be sold and updated to new one.” (B, 20's)

Being involved in the luxury second-hand market requires an increasing level of knowledge about pricing, changing trends, brands, and iconic pieces. Re-sell activities encourage the emergence of a form of entrepreneurial luxury consumer, who sell to purchase and purchase to sell conventional items in a planned manner.

"I guess selling had an influence of my perception of the luxury market. Chanel, Hermès never lose their value. Instead, Isabel Marant, Alexander McQueen, Kenzo sell very well at the moment. Will they sell in a couple of years? Not sure. I prefer purchasing items with a long-term value. I sold two Lancel bags to purchase a Celine bag. I had it hot stamped. It is my bag. I will not resell it [...] I continue purchasing brand-new items of the moment, with visible brand codes, to make sure they are easy to resell. With the resell price, I reward myself with products I will keep forever.” (M, 30's)

\subsection{The social value of selling luxury: Sellers' enactment of social roles}

As indicated in the section above, on the second-hand market, there is a shift in the symbolic meaning of luxury goods, from being an experiential, emotional good to becoming the mere object of a financial transaction, sometimes gaining speculative value. Selling also entails an evolution in sellers' enactment of their social roles. The perceived social value that sellers derive from the selling activity contributes to a new, emerging, unconventional luxury consumption phenomenon. 


\subsubsection{Reconfiguration of the social hierarchy between sellers and buyers}

For long, selling and purchasing second-hand goods was stigmatized: among the affluent, selling ones' possessions was a signal of financial distress. With the development of second-hand luxury platforms, this activity is now socially accepted (Ferraro et al., 2016). This contributes to the democratization of luxury, giving access to luxury goods to a larger group of consumers (see e.g. Kastanakis \& Balabanis, 2012). Selling as an activity gains value because of the increasing demand and relatively lower supply (see e.g. Leibenstein, 1950). This leads to the emergence of a new form of self-identification with a higher consumer status.

"At the beginning, when I started selling, I was feeling uncomfortable. I did not want my relatives think I was lacking money or undergoing a difficult financial situation. I was selling in physical stores and I was hiding this activity from my friends. Later on, the boom of the second-hand online platforms helped me take responsibility for selling.” (L, 30’s)

Just like L, many respondents described how they felt they had to justify their activity and hide their behaviour from others in order to preserve their status. Luxury sellers who would never buy secondhand for themselves wanted to draw a clear line between buyers and sellers: Second-hand luxury buyers are suggested to be social climbers (Kessous \& Valette-Florence, 2019) who purchase status markers; second-hand luxury sellers purchase an experience of status as a first-hand customer that they might finance through their selling activity. In this view, the aim of luxury consumption is not displaying a luxury good but being a luxury client. P compares the second-hand luxury ecosystem to Airbnb: she rents her apartment on the platform, but she goes on holidays to a hotel. The apartment has a functional value (somewhere to sleep) whereas the hotel has an experiential one (somewhere to spend a pleasurable moment). Sellers trade off a luxury good for a status of luxury client. The ceremonial in the boutiques, the personal attention from salespeople, legitimize this 
status of luxury and acknowledge their position in the social hierarchy (Dion \& Borraz, 2017). A form of snobbism is expressed when dissociating from the group of second-hand purchasers (Kastanakis \& Balabanis, 2012):

"I would never ever purchase second-hand items. I love the luxury experience too much. It is not only about the handbag; it is the box, the silk paper. It is the coffee offered in the boutique, taking the time to discuss the heritage of the brand. It is also about being in the listings of loyal clients, being invited to private parties.” (C, 20’s)

Being considered as a luxury client by luxury brands confers status; being invited to private sales confers another form of prestige. Yet, this prestige might be lost if $\mathrm{C}$ is caught reselling her private sales purchases on the second-hand market and thus blacklisted by the luxury brands. Anticipation of these negative consequences lead some sellers to create multiple identities, which is C's way of addressing these restrictions, and/or avoid selling private sales items on official second-hand channels under her own name. The social intimidation in the service encounter described by Dion and Borraz (2017) is expressed here through hiding the shameful reselling activity. In a similar vein, sellers fear being spotted as selling fakes. All respondents emphasized how important the certified authenticity is when the goods are bought from secondary channels. Re-sellers do not want to lose their credibility vis a vis of both buyers and intermediary platforms.

"I had purchased a pair of Louboutin shoes on Ebay when I was younger. I never wore them. I cannot sell them on the second-hand market because I am not $100 \%$ sure they are genuine. I am torn. I do not want to be caught selling counterfeits. I only sell objects I have kept with the original packaging. For most of them, I can prove the authenticity; I keep the invoice or I can track my order back years.” (M, 30's) 
Sellers recognize that selling expensive, branded, luxury goods is an expression of their wealth. Sellers have a dominant position in the transaction; owning the object they paid full price for, brings the power to the negotiation room. These interactions produce buyer-seller status games, where each party enacts a social class position (Dion \& Borraz, 2017). Performing a higher status role helps sellers consolidate their status as legitimate luxury consumers.

"Buyers always negotiate. The motivation of the buyer on the second-hand market is getting branded items at the lowest price. I often refuse price decreases. Sometimes, when I enter in a conversation with the buyer, I decide to lower the price because I know she cannot afford the item she is dreaming of." (L, 30's)

$\mathrm{M}, \mathrm{L}$ and $\mathrm{D}$, recount stories of transactions where the purchasers are in the position of subordinates and the sellers act with magnanimity. The sellers have the power to accept or refuse the price proposed by the buyers. L sometimes generously accepts to sell at a lower price than expected because she takes for granted the purchaser is less wealthy than she is. Furthermore, sellers may further demonstrate their status by the number of products they have sold and at which prices. M confesses she likes the fact that Vestiaire Collective does not remove the sold items from the list. This is a demonstration of power: selling highly priced goods and showcasing them in a virtual closet on the platform can serve as a signal of wealth and social status. Ultimately, when a seller is at the top of the social hierarchy, a personal shopper from the second-hand luxury outlet comes to the sellers' house, select the items, estimates the prices and carries the items. This deference is a marker of a social class and a way to manage the status of VISs (Very Important Sellers), in much the same way as luxury houses manage VICs (Very Important Clients).

\subsubsection{Higher environmental consumer status: selling luxury to fit into the circular economy}


A further form of status emerged from the data related to second-hand luxury selling, albeit of a more subtle and surprising nature, that of a responsible consumer. These consumers regard the second-hand channel as a means to extend the luxury product's lifecycle, and thus, link sustainability with luxury. The luxury experience is derived through actual usage of the product and its preservation for a next generation of consumers. These eco-centered motives (Cervellon \& Shammas, 2013) of "doing good" for the planet alleviate their moral concerns relating to the purchasing of superfluous goods. Extending the product's lifecycle through a second-hand activity becomes an objective very early on in the consumption process, sometimes right at the beginning with the purchase of goods that have quality and durability and might be resold. They may even purchase luxury goods speculating on the durability of those goods by comparison to fast-fashion items; the re-sell value in this case is not based on the economic value but on the long-term quality of the good.

"I entered to world of second-hand luxury handbags by being first a purchaser. Nowadays, I am also involved in selling, as I realized that it is a limited number of bags I really need. (...) For me, selling as well as buying luxury as a second-hand is way to be more sustainable and greener, because it extends the life of the products that are high quality." (T, 20's)

In this sample, informants who were concerned about safeguarding their eco-friendly lifestyle without compromising on style and fashionability, were often both buyers and sellers of secondhand luxury goods. They searched actively to rationalize their behaviour - from an environmental perspective as $\mathrm{X}$ explains:

“I see myself just as one possessor during the products' lifecycle, not as an end-customer. The extremely high quality and timeless design of the luxury handbag make it possible to sell for a new owner (...) Maybe I am justifying luxury purchases by selling, but I get a 
good conscience by knowing that luxury goods are not mass produced and besides, that the environmental impact of the product is much smaller when there are more usage times and users for these quality products." (X, 30's)

In addition to the sustainability motives, Griskevicius et al. (2010) also suggest that purchasing green products might be a way of demonstrating status and therefore can also be said to be consuming conspicuously: "Going green to be seen". In the same vein, selling luxury goods with sustainability motives allows a way of being seen as a better consumer, a smarter consumer, and a greener consumer. These sellers have the feeling they contribute more to the preservation of the environment; they are leaders, they show the way; they are more responsible than the average citizen, because they contribute to the durability of the fashion cycles. The more the sellers recycle, the more powerful their actions, the more powerful they are.

"By being involved in selling and also buying luxury goods in secondary market I would like to show an example for others how it is responsible to invest in high quality goods although it is luxury branded products! You can make wise and sustainable decisions in the luxury context as well. (...) These products often even get better with age, for example, leather, which in general is not such a sustainable material, but as second-hand I see it as acceptable.” (H, 40’s)

The emergence of an eco-consciousness surrounding the benefits of the second-hand luxury market is an additional facet to this complex area. Particularly, luxury consumers might feel guilty regarding their "superfluous" consumption and selling pre-owned luxury might be a compensatory behaviour and a way to alleviate moral concerns:

"I feel concerned sometimes that I spend so much on luxury handbags. I have friends who queued when Primark opened a store nearby... It is embarrassing that one of my bags is 
worth their yearly fashion spending. At the same time, fast fashion items do not last. I do not throw away; I sell.” (L, 30's)

\section{Conclusion and implications}

Our findings demonstrate that selling luxury goods brings value to the sellers in a unique way, related to both the nature of the good and the nature of the activity. First, there is an alteration of the personal value of luxury consumption for sellers. Luxury goods have a strong resonance to the owner, based on the emotional bond and the hedonic experience derived from the purchase and usage of the good. The process of disposing through selling entails erasing personal meaning and memories, toning down the emotional value, and evaluating in a rational way the economic value of the good. As sellers gain expertise in the process, they might speculate on the resell value of the luxury goods when initiating the purchase. The process of re-selling reduces luxury goods to the objects of a financial transaction. At the same time, it is a source of empowerment for luxury consumers as it confers expertise and financial control. As the second-hand market is growing worldwide, conventional luxury consumption is likely to evolve based on planned and unplanned re-selling. In 2018, 44\% of true-luxury consumers consider the resale value of the new luxury items they purchase (BCG, 2019). Luxury goods purchased for planned re-sell are status symbols, conspicuous and brand icons that are easy to dispose of (Han et al., 2010). Also, hard to get items and limited editions are products sought after on the second-hand market that justify a speculative value (Jang \& Mouthino, 2015; Turunen \& Pöyry, 2019).

Second, selling second-hand luxury involves a change in the luxury consumer social role. For some sellers, the act of selling second-hand luxury items bestows on the seller the perception of 
belonging to a higher echelon social status, as they would never indulge in the purchase for themselves. They would only purchase luxury branded items first-hand and they are merely supplying the market and consumers below them in status with the opportunity to access these goods. In the negotiation room, sellers-purchasers perform a social role game: sellers have the decision-making power (Dion \& Borraz, 2019). Sellers are set apart from luxury second-hand consumers, focused on the acquisition of material goods as they experience the status of luxury clients. The development of second-hand luxury markets encourages the dichotomy between clients of luxury who purchase to live the luxury experience and consumers of luxury who purchase to display the material good. The democratization of luxury encouraged by the development of the second-hand market parallels the development of a new elitism, which is not materialistic but focused on experiencing luxury.

For other sellers, the self-perceived consumer status shift took place in relation to contributing towards the circular economy. In this case, the brand and product have less importance than the act of passing the goods on, extending their life. The values attached to recycling and re-using are crucial to the ethos of the circular economy and convey the perception of a higher environmental consumer status. This points to a subtle form of conspicuous consumption and status signalling (Griskevicius et al., 2010): the more they sell, the more they have. This demonstration of power is similar to the Potlatch ceremony that was practiced by several first nations groups in North America until the beginning of the Twentieth Century. It involved giving (and sometimes destroying) valuable goods as a signal of the ability to waste resources, thus functioning as a signal of status for the most generous, who give away the most.

Theoretical contribution and future research 
Three main theoretical conclusions can be outlined from our study. First, the study provides a new perspective in approaching second-hand luxury - through the seller's perspective - which supplements the current literature on second-hand luxury consumption. Whilst there exists a growing body of literature concerned with buying and consuming second-hand luxury goods (Cervellon et al., 2012; Turunen \& Leipämaa-Leskinen, 2015; Ryding et al., 2018; Kessous \& Valette-Florence, 2019), the transformation of the luxury consumer to a seller has been neglected in prior literature. Thus, by suggesting the diverse dynamics driving the decisions to sell luxury goods, we aim to contribute theoretically towards the closing of this research gap. Studying the buying and selling process-related meanings for sellers, we identified an evolution in the underlying drivers attached to luxury consumption, first in the personal value of luxury goods. Aside from emotional and experiential values that are attached to conventional luxury purchases, the development of the second-hand market adds a new economic value, a speculative value, to the good. The perspective of re-selling the good for money is a means of consumer empowerment, through the growth of expertise and potential financial resources.

Second, this research also contributes to the literature on status signaling. Although a large body of research has examined how consumers use goods to signal their status through purchase and consumption (Berger \& Ward, 2010; Han et al., 2010), the topic lacks clarification from the disposal stage. Selling unravels unconventional ways of embodying higher social roles on the luxury market. Being a luxury client and reselling goods purchased first-hand is a new way of demonstrating and displaying a superior status versus being a consumer of luxury goods. Signaling theory is a useful framework to explain how selling behaviours might yield prestige to the sellers (Cummins, 2005). Selling luxury goods involves accepting the monetary loss and detaching from a good that is sought by many purchasers, a costly signal which confers prestige to the seller. We 
suggest, a new form of conspicuous consumption might emerge, based on the conspicuous reselling of luxury goods. Once a shameful activity, reselling luxury goods has gained prestige.

Third, our research adds to the sustainable luxury literature (Achabou \& Dekhili, 2013; Turunen \& Leipämaa-Leskinen, 2015, Kessous \& Valette-Florence, 2019) by demonstrating additional motivations to the disposal of luxury goods (Lee et al., 2015): besides extending the lifecycle of products, enacting the role of responsible citizens who purchase durable goods that last and have a re-sell value. Again, the act of disposal through selling confers a prestige to the seller, in line with the Griskevicious et al. (2010) findings.

Furthermore, these findings unveil the contemporary facets of the luxury concept, pinpointing the consumer's active role in the value creation process and the under-estimated, emerging dimension of re-sale value (Turunen \& Pöyry, 2019). Thus, the findings challenge the traditional understanding where brand and company play key roles in building and curating the perception of luxury (Dion \& Borraz, 2017). Luxury brand value (Hermès is a particular example) is largely determined in the present time by their re-sale value on the second-hand market. Future research could delve deeper into this new value creation process that takes place on alternative markets such as second-hand or renting, in countries with different perspectives on luxury and sustainability, as well as in product categories that are more gender specific (such as the watch sector). In addition, with future research, the limitations of our study could be supplemented: Besides collecting larger data sets from multicultural contexts, both genders could be included in the data collection. Our data consists of women, as they are the first source of sales on second-hand luxury fashion platforms.

\section{Managerial implications}


The findings suggest that contemporary luxury consumers do not necessarily regard themselves as end-customers, but instead as a moveable owner during the product's lifecycle. Luxury brands should acknowledge and turn this into a benefit: they could endeavor to manage the whole lifecycle of the product to bring value to it during all the consumption phases - not just in the initial "firsttime" purchasing situation, but instead, bring value through additional services for further users and possessors during the lifecycle of the product. First, building a long-term relationship with clients, recognizing first-hand luxury clients, providing an experience that is not product-centered, confers prestige to the client and value to the brand. Experiencing the status of a luxury client emerged as a strong motivation of our sellers when they purchase in the boutiques. Luxury brands should now embrace the opportunity to recognize the status of second-hand sellers, providing them with an exclusive shopping experience. In the beginning of October 2019, Burberry initiated a partnership with the consignment platform TheRealReal, in order to encourage a circular economy. Sellers of pre-owned Burberry items, emptying their cupboard on the RealReal platform, enjoy champagne in Burberry's boutiques whilst admiring the latest collections, pre-ordering them and feeling the privileged status of a luxury client. Second, being able to control the re-selling process, advising sellers on price estimations, authentication of products, repair and cleaning services, would be a way to increase the brand value on the second-hand market and strengthen the relationship with this new segment of clients who purchase to sell, and sell to purchase. Luxury conglomerates have started getting involved in the new second-hand business models: Richemont acquired Watchfinder in 2018 and many high-end jewelers such as Cartier have opened outlets specialized in the restauration of second-hand and vintage jewels. Ultimately, the objective is to increase the resale value of the goods and avoid having too many branded products sold at a low price, which might harm the image of exclusivity of the brand. Two directions have already been explored by luxury brands: limiting the quantities of certain models on the market, limited editions being very often more expensive on the second-hand market than when purchased first-hand in the boutiques; 
limiting the products sold on private sales that very often end up on the second-hand market without being used, or putting a marker identifying the item as a private sales item. These measures have the positive consequences of reinforcing the resale value, and consequently the brand value, as well as legitimizing the status position of the sellers as clients of luxury houses.

\section{References}

Achabou, M. A., \& Dekhili, S. (2013). Luxury and sustainable development: Is there a match? Journal of Business Research, 66(10), 1896-1903.

Amatulli, C., Pino, G., De Angelis, M. \& Cascio, R. (2018). Understanding purchase determinants of luxury vintage products. Psychology \& Marketing, 35(8), 616-624.

Beard, N.D. (2008). The branding of ethical fashion and the consumer: a luxury niche or massmarket reality? Fashion Theory, 12(4), 447-467.

Bearden, W.O., \& Etzel, M.J. (1982). Reference group influence on product and brand purchase decisions. Journal of Consumer Research, 9(2), 183-194.

Belk, R.W. (1988). Possessions and the Extended Self. Journal of Consumer Research, 15(9), 139168.

Belk, R.W., Fisher, E., \& Kozinets, R.V. (2013). Qualitative Consumer \& Marketing Research, Los Angeles: Sage. 
Belk, R.W., Sherry Jr, J.F., \& Wallendorf, M. (1988). A naturalistic inquiry into buyer and seller behavior at a swap meet. Journal of Consumer Research, 14(4), 449-470.

Berger, J., \& Ward, M. (2010). Subtle signals of inconspicuous consumption. Journal of Consumer Research, 37(4), 555-569.

Berthon, P., Pitt, L., Parent, M., \& Berthon, J.P. (2009). Aesthetics and ephemerality: observing and preserving the luxury brand. California Management Review, 52(1), 45-66.

Boston Consulting Group (2019) True Luxury Consumer Global Insight, $6^{\text {th }}$ edition. Last accessed September $22^{\text {nd }} 2019$.

Carrigan, M., Moraes, C., \& McEachern, M. (2013). From conspicuous to considered fashion: A harm-chain approach to the responsibilities of luxury-fashion businesses. Journal of Marketing Management, 29(11-12), 1277-1307.

Cervellon, M.C., Carey, L., \& Harms, T. (2012). Something old, something used: Determinants of women's purchase of vintage fashion vs second-hand fashion. International Journal of Retail and Distribution Management, 40(12), 956-974.

Cervellon, M.C., \& Shammas, L. (2013). The Value of Sustainable Luxury in Mature Markets. Journal of Corporate Citizenship, 52(12), 90-101. 
Cervellon, M.C., \& Vigreux, E. (2018). Narrative and emotional accounts of secondhand luxury purchases along the customer journey. In Vintage Luxury Fashion (pp. 79-95). Palgrave Macmillan, Cham.

Chu, H., \& Liao, S. (2010). Buying while expecting to sell: The economic psychology of online resale. Journal of Business Research, 63(9-10), 1073-1078.

Cruz-Cárdenas, J., \& Arévalo-Chávez, P. (2018). Consumer behavior in the disposal of products: Forty years of research. Journal of Promotion Management, 24(5), 617-636.

Cummins, D. (2005). Dominance, status, and social hierarchies. In The Handbook of Evolutionary Psychology (pp. 676-697). Wiley and Sons.

Dion, D., \& Borraz, S. (2017). Managing Status: How Luxury Brands Shape Class Subjectivities in the Service Encounter. Journal of Marketing, 81(5), 67-85.

Eastman, J.K., Goldsmith, R.E., \& Flynn, L.R. (1999). Status consumption in consumer behavior: Scale development and validation. Journal of Marketing Theory and Practice, 7(3), 41-52.

Ferraro, C., Sands, S. \& Brace-Govan, J. (2016). The role of fashionability in second-hand shopping motivations. Journal of Retailing and Consumer Services, 32(9), 262-268.

Fournier, S. (1994). A consumer-brand relationship framework for strategic brand management. Ph.D. dissertation, University of Florida, Gainesville. 
Gerval, O. (2008). Fashion: Concept to catwalk. London: Bloomsbury.

Gil, L.A., Kwon, K.N., Good, L.K., \& Johnson, L.W. (2012). Impact of self on attitudes toward luxury brands among teens. Journal of Business Research, 65(10), 1425-1433

Griskevicius, V., Tybur, J.M., \& Van den Bergh, B. (2010). Going green to be seen: status, reputation, and conspicuous conservation. Journal of Personality and Social Psychology, 98(3), 392-404.

Grunert, K.G., \& Grunert, S.C. (1995). Measuring subjective meaning structures by the laddering method: Theoretical considerations and methodological problems. International Journal of Research in Marketing, 12(3), 209-225.

Han, Y.J., Nunes, J.C., \& Drèze, X. (2010). Signaling status with luxury goods: The role of brand prominence. Journal of Marketing, 74(4), 15-30.

Hagtvedt, H., \& Patrick, V.M. (2009). The broad embrace of luxury: Hedonic potential as a driver of brand extendibility. Journal of Consumer Psychology, 19(4), 608-618.

Jang, S., \& Moutinho, L. (2015). Effects of contextual promotions and online information on revenue performance in luxury hotel industry: An empirical investigation of global resort hotels. In 2015 Global Fashion Management Conference, Florence, 105-112.

Kastanakis, M.N., \& Balabanis, G. (2012). Between the mass and the class: Antecedents of the “bandwagon” luxury consumption behavior. Journal of Business Research, 65(10), 1399-1407. 
Kastanakis, M.N., \& Balabanis, G. (2014). Explaining variation in conspicuous luxury consumption: An individual differences' perspective. Journal of Business Research, 67(10), 21472154.

Kessous, A., \& Valette-Florence, P. (2019). "From Prada to Nada": Consumers and their luxury products: A contrast between second-hand and first-hand luxury products. Journal of Business Research, 102(9), 313-327.

Kessous, A., Valette-Florence, P., \& De Barnier, V. (2017). Luxury watch possession and dispossession from father to son: A poisoned gift? Journal of Business Research, 77(8), 212-222.

Lastovicka, J.L., \& Fernandez, K.V. (2005). Three paths to disposition: The movement of meaningful possessions to strangers. Journal of Consumer Research, 31(4), 813-823

Lee, M., Ko, E., Lee, S., \& Kim, K. (2015). Understanding luxury disposition. Psychology \& Marketing, 32(4), 467-480.

Leibenstein, H. (1950). Bandwagon, snob, and Veblen effects in the theory of consumers' demand. The Quarterly Journal of Economics, 64(2), 183-207.

Liao, S., \& Chu, H. (2013). Influence of consumer online resale awareness on purchase decisions: a mental accounting perspective. European Journal of Marketing, 47(10), 1576-1597. 
McCracken, G. (1986). Culture and consumption: A theoretical account of the structure and movement of the cultural meaning of consumer goods. Journal of Consumer Research, 13(1), 7184.

Mandel, N., Petrova, P.K., \& Cialdini, R.B. (2006). Images of success and the preference for luxury brands. Journal of Consumer Psychology, 16(1), 57-69.

Nelissen, R.M., \& Meijers, M.H. (2011). Social benefits of luxury brands as costly signals of wealth and status. Evolution and Human Behavior, 32(5), 343-355.

Noble, C.H., \& Walker, B.A. (1997). Exploring the relationships among liminal transitions, symbolic consumption, and the extended self. Psychology and Marketing, 14(1), 29-47.

O'Cass, A., \& McEwen, H. (2004). Exploring consumer status and conspicuous consumption. Journal of Consumer Behaviour: An International Research Review, 4(1), 25-39.

Roster, C.A. (2001). Letting go: The process and meaning of dispossession in the lives of consumers. In M. C. Gilly, \& J. Meyers-Levy (Eds.), Advances in Consumer Research, 28, pp. 425430. GA: Association for Consumer Research.

Ryding, D., Henninger, C.E., \& Cano, M.B. (Eds.) (2018). Vintage Luxury Fashion: Exploring the Rise of the Secondhand Clothing Trade. Springer.

Spiggle, S. (1994). Analysis and interpretation of qualitative data in consumer research. Journal of Consumer Research, 21(3), 491-503. 
Turunen, L.L.M., \& Leipämaa-Leskinen, H. (2015). Pre-loved luxury: identifying the meanings of second-hand luxury possessions. Journal of Product and Brand Management, 24(1), 57-65.

Turunen, L.L.M., \& Pöyry, E. (2019). Shopping with the resale value in mind: A study of secondhand luxury consumers. International Journal of Consumer Studies, doi: 10.1111/ijcs.12539.

Vigneron, F., \& Johnson, L.W. (1999). A review and a conceptual framework of prestige-seeking consumer behavior. Academy of Marketing Science Review, 1(1), 1-15.

Young, M.M., \& Wallendorf, M. (1989). Ashes to ashes, dust to dust: Conceptualizing consumer disposition of possessions. In Proceedings of the AMA winter educator's conference (pp. 33-39). 